\title{
Selected Aspects of Age Management as a Challenge for Polish Entrepreneurs
}

\author{
Monika Sipa, Andrzej Skibiński \\ Czestochowa University of Technology, Poland \\ monikasipa@gmail.com
}

\begin{abstract}
The process of demographic aging is not only a long-term threat to the maintenance of social security systems, but also a major challenge for the companies in terms of the HR function implementation. It is necessary that employers take a more responsible attitude to the problems of an aging population in order to provide the proper functioning not only of these organisations, but also of the whole society and economy. This paper presents some aspects of age management in the context of the perception of this problem by Polish employers. The main objective of this elaboration was to determine whether and how Polish organisations view the problem of aging of labour force.
\end{abstract}

Keywords: Employee, entrepreneur, age management, HR, manager

\section{Introduction}

The changes occurring in the contemporary world are characterised by an ageing society and relatively low fertility rates. The ageing of the society is a worldwide problem. The changes also involve a decrease in the workforce, which means that in the future there may be a shortage of employees and problems connected with the existing retirement systems. This is not only a macroeconomic problem. The anticipated demographic changes force employers to face new challenges in terms of human resources management. Noticing those threats has resulted in an increased interest in problems concerning age management at enterprises. However, it should be borne in mind that this is not a new issue. Numerous countries, particularly Scandinavian ones, have noticed the problem of ageing of the society many years ago, hence the results of actions taken to manage the age of the society are already visible (more: Magd, 2003). In 2013, the terms of the employment rate for people aged 55-64 in Poland stood at $40.6 \%$ of people in that age category are employed. There are $43.5 \%$ of employees in average across the European Union in that age group (EC).

An increasing number of organisations, including those in Poland, undertakes or will soon be forced to undertake various activities in terms of age management. The activities are connected with the creation of favourable work conditions for employees from various age groups, which are aimed at improving the work environment, extending the period of professional activity of individuals and keeping older adults at their workplace despite reaching the retirement age. Currently more and more managers notice the great potential of experienced personnel. Knowledge, competence and skills of many senior citizens can have a positive impact on economic entities, and the proper transfer of duties to such employees in connection with the creation of teams or work groups can help reform enterprise operations and result in tangible benefits. Age management, however, requires numerous bold decisions to be made, which may have strategic significance for the future of an organisation. It is connected, for instance, with a material change in the manner of functioning of units, which translates into a range of organisational changes. The piling up barriers are such a significant challenge for organisations, that they prevent taking steps to introduce changes in terms of age management. Due to the advancing ageing of the Polish society, employers will soon need to face a challenge in the form of creation of favourable work conditions for employees from various age groups. Therefore, it is required to increase the emphasis on the age-positive policy development, creation of systems for intergenerational learning systems and systems connected with security, healthcare, as well as a more holistic approach to human resources planning (Eurofound, 2007).

In this paper the authors present a fragment of pilot studies concerning the problems of age management in Polish organisations. The main objective was to determine whether and how Polish organizations view the problem of the aging of labour force. There was made an attempt to answer the following questions: (1) is the problem of an aging workforce noticed by Polish enterprises and what is the attitude of the management 
towards the employees in this age group? (2) What age group, according to staff, is preferred by Polish employers? (3) Are the elements concerning the implementation of age management with respect to the elderly respected in the field of human resource management? (4) Is the intergenerational cooperation present in organisations and what are its effects? (5) Is the discrimination of workers based on age present in Polish enterprises?

\section{The essence of age management in the context of human resources management}

Age management is a broadly understood notion which is used in various contexts. It is connected with numerous terms, such as: ageing society, demographics, active ageing, and management at all ages, diversity management, discrimination prevention. As Liwiński \& Sztanderska (2010) emphasise, age management is a component of human resources management or, more precisely, a component of diversity management. It consists in executing activities which lead to a rational and efficient use of human resources at enterprises by considering the needs and abilities of people at different ages, as well as to increase the efficiency of work of older people. The utilisation of those differences contributes to the creation of a creative environment in which everyone will feel appreciated, the abilities of individual members of the team will be utilised to their full extent and the goals of the organisation will be achieved (Kandola \& Fullerton, 1994). This is stressed e.g. by Lemańska-Majdzik \& Sipa (2015) in relation to family businesses. Age management is a constantly developing collection of methods for investing and caring for company's human resources so that the work of an individual, regardless of their age, would generate profits for the company and personal satisfaction.

The European Foundation for the Improvement of Living and Working Conditions (2007) indicates that age management can be considered on three various levels: individual, enterprise and labour market structure. In case of the individual level actions directed at senior citizens are mentioned, which are aimed at increasing their chances on the labour market (both for those who are employed and those who are unemployed) by constantly updating their skills and basic knowledge. As Dzieńdziora \& Smolarek (2009) noticed, in terms of the employment policy the recruitment of employees is primarily executed on the basis of employee qualifications and their competence. Considering the level of an enterprise, which is the essence of this paper, it is emphasised that age management can be perceived also from the point of view of human resources at the enterprise. The problems are usually noticed during: a restructurisation, changes on the market, organisational changes, technological development, loss of skills, lack of employment or the policy of labour unions. This is stressed e.g. by Gorzeń-Mitka (2014) in relation to family businesses and Okręglicka (2014) to small and medium enterprises. Also, the specific nature of a company, the pressure of costs, consumers' needs, flexible production needs and the maintenance of a qualified workforce, as well as changes in social values at the company influence the decisions made in that scope and the adoption of age management. The final, third level refers to activities connected with age management at various political and labour market levels, starting from international organisations up to local government strategies (Eurofound 2007).

The literature (Casey, Metcalf \& Lakey, 1993) mentions five main dimensions of age management at organisations. These are as follows: job recruitment and exit; training, development and promotion; flexible working practice; ergonomics and job design; changing attitudes towards ageing workers. A slightly different division of areas of age management at organisations was presented by Naegele \& Walker (2006). They mention: recruitment and selection; professional career development; flexible forms of employment; health protection and promotion; redeployment; the end of employment and transition to retirement. The introduction of age management in enterprises requires an increased awareness of the management and employees, both in terms of threats and opportunities connected with the ageing of the labour force and the changing environment at enterprises. Age management is pointless if there is any practices at the company which concern discrimination on the grounds of age. It is important for the policy of equal chances to be pursued in that scope. Employers should not tolerate direct or indirect discrimination of any employee, regardless of whether it is on the grounds of race, nationality, sex, sexual orientation, disabilities, beliefs, marital status or age (Armstrong, 2011).

An age management strategy at a particular firm and its objectives should be outlined based on a broader vision of values, on which a particular organisation is based and the current personal policy at the firm. Good and comprehensive age management not only increases the potential of older employees, but it also leads to 
its efficient utilisation. International research (Magd, 2003; Reday-Mulvane, 2005; Mahlberg et al., 2013) shows that the immobile age of employees did not have a negative influence on the efficiency of their work and, consequently, on the efficiency of enterprise operations (depending on the specific nature of performed work). Therefore, the need to change the attitude toward older people as quickly as possible and counteract the harmful stereotype saying that this group is socially useless and constitutes a burden to the society has been noticed. According to the European Commission (2006) taking steps in the area of age management may bring benefits to enterprises in the form of: a better adjustment of workforce in terms of work experience to job requirements; a reduction of direct and indirect costs of medical leaves and substitutions; an improvement of relationships with clients, who are more frequently people aged 50+ due to the common process of ageing of the society, who prefer contacting company representatives of similar age. transfer of knowledge in organisations; a better utilisation of individual employee capabilities, an increase in the motivation of older employees to work, an increased flexibility in terms of adjusting to quickly changing conditions through expanding employee skill sets. It is worth analysing the construction of an age management policy as a component of strategic management.

Demographic conditions for age management in Poland-selected indices: Organisational management is always executed in certain conditions, which are composed of numerous factors both inside and outside the organisation. As Pocztowski (2007) mentioned the external environment of personnel functions in human resources management consists of other enterprises, labour market participants and features of the macro environment of the following nature: technical, economic, legal, socio-cultural, ecological and demographic. Demographic features have a strong influence on demand for labour, which indirectly influences decisions in terms of the personnel function at the enterprise (Skibiński, 2012). By focusing on demographic changes, which are very important from the point of view of age management, the ageing of the population can be observed. As the data analysis shows (Tab. 1) the systematic increase in the percentage of people aged 65 or more with regard to the percentage of population aged 15-64, i.e. the working age population, is visible in Poland as well. Also, the decrease in the number of people in the pre-working age group, i.e. aged 0-14 is dangerous, because it means that the process of a decrease in the working age population is accompanied by the ageing of the labour force.

Table 1: Selected amounts characterising the demographic situation in Poland (forecasts included)

\begin{tabular}{lllllll}
\hline \multirow{2}{*}{ Selected indices } & & $\begin{array}{l}\text { Years } \\
\text { 1990 }\end{array}$ & $\mathbf{2 0 1 0}$ & $\mathbf{2 0 3 0} *$ & $\mathbf{2 0 5 0}$ & $\begin{array}{l}\text { Change } \\
\mathbf{( 2 0 1 0 - 2 0 5 0 )}\end{array}$ \\
\hline Percentage of population & 0-14 years old & 21.5 & 15.0 & 15.0 & 13.9 & -1.1 \\
according to economic & 15-64 years old & 64.8 & 71.5 & 62.9 & 57.0 & -14.5 \\
age groups [\%] & 65 and older & 10.1 & 13.5 & 22.1 & 29.1 & +15.6 \\
& Male & 66.5 & 72.1 & 75.8 & 78.7 & +6.6 \\
Life expectancy [years] & Female & 75.5 & 80.6 & 82.7 & 85.1 & +4.5 \\
Fertility rate & & 2.1 & 1.4 & 1.6 & 1.7 & +0.3 \\
\hline
\end{tabular}

* Forecasts

Source: own study based on: World Data Bank and Eurostat

The process of ageing of the population is also accompanied by an increase in life expectancy, both for men and women. It is expected that the increase in the average life expectancy between 2010 and 2050 will amount to 6 years in case of men and almost 5 years in case of women. Therefore, on the one hand there is an increase in life expectancy, and on the other hand there is a low fertility rate, which leads to a decrease in potential labour force.

\section{Methodology}

The analysis was conducted at the turn of March and April $2015^{1}$ using a diagnostic survey. A survey questionnaire was used, which comprised of 23 open-ended, semi-open-ended and closed-ended

\footnotetext{
${ }^{1}$ This is a pilot study and it constitutes an introduction to further research in the scope of the analysed research problem.
} 
dichotomous and cafeteria questions as well as demographics. Questions used nominal, relative and rank order scaling. The selection of the research sample was executed using the method of non-probability sampling. The $\mathrm{N}=138$ research sample comprised of students of part-time studies at the Faculty of Management at the Częstochowa University of Technology. An important premise for the selection of the research sample was the fact that the respondents are employed and they belong to various working age groups. They also have certain work experience and knowledge on the functioning of enterprises at which they are employed. The characteristic features of respondents show, that the researched group was mainly comprised of women-52.2\%. Most of respondents were employees up to the age of $40(72.5 \%)$, whereas the most numerous group comprised people aged 25-34, to which as many as $1 / 3$ of respondents belonged. Regular employees, among whom most are women-60.9\% of that group-are the largest group among the respondents. As much as $1 / 3$ of respondents are managers, of whom most are men, particularly among senior managers $(80.0 \%$ are men). Almost half of respondents $(49.3 \%)$ are employees with a relatively short period of being employed at organisations which were their current workplace at the moment of the analysis. As much as $27.5 \%$ of respondents indicated a period of employment of over 10 years. The characteristics of the research sample are presented in Table 2.

Table 2: Group characteristics

\begin{tabular}{lll}
\hline FEATURES & & PERCENTAGE \\
\hline & up to 25 years old & $23.2 \%$ \\
Age group & $25-34$ years old & $33.3 \%$ \\
& $35-39$ years old & $15.9 \%$ \\
& $40-44$ years old & $20.3 \%$ \\
Employment period at the organisation & $45-49$ years old & $5.8 \%$ \\
& 50 or older & $1.4 \%$ \\
Type of performed work & less than 5 years & $49.3 \%$ \\
& 5-10 years & $23.2 \%$ \\
& more than 10 years & $27.5 \%$ \\
Professional status at the organisation & Physical & $17.4 \%$ \\
& intellectual & $60.9 \%$ \\
& mixed-type & $21.7 \%$ \\
& senior management & $7.2 \%$ \\
& junior management & $26.1 \%$ \\
\hline
\end{tabular}

Source: own work based on survey

\section{Selected results of the analysis}

White attempting to characterise entities at which the respondents are employed it should be noted that they are mostly organisations providing services-55.1\%. Operations in the area of production or trade were indicated by $11.6 \%$ of respondents. In the case of remaining firms a mixed profile of operations was indicated. Almost $3 / 4$ (73.9\%) are private entities. More than half of respondents work at entities from the SME sectorthey comprise $55.1 \%$ of respondents. The remaining respondents are employed at large corporations employing over 250 people. Microenterprises (up to 9 employees) are the workplace for 20.3\% of respondents. There is a clear domination of employees aged 26-45 at analysed organisations-they constitute $90.1 \%$ of all indications. The group, however, is dominated by employees aged 36-45. Very young employees (less than 25 years old) and those aged 46-49 each comprise only $4.3 \%$ of employees at the organisations. (Fig. 1) The results show that the occurrence of ageism is still a significant problem in Poland, mainly with regard to senior citizens. If one were to look at the wealthy Western European countries, then he would see that persons who have yet 15-20 years left to reach the retirement age are still active on the labour market and they contribute to the economic growth of those countries (more: Szukalski, 2009). 
Figure 1: The average age of employees at the respondents' workplace

up to 25 years

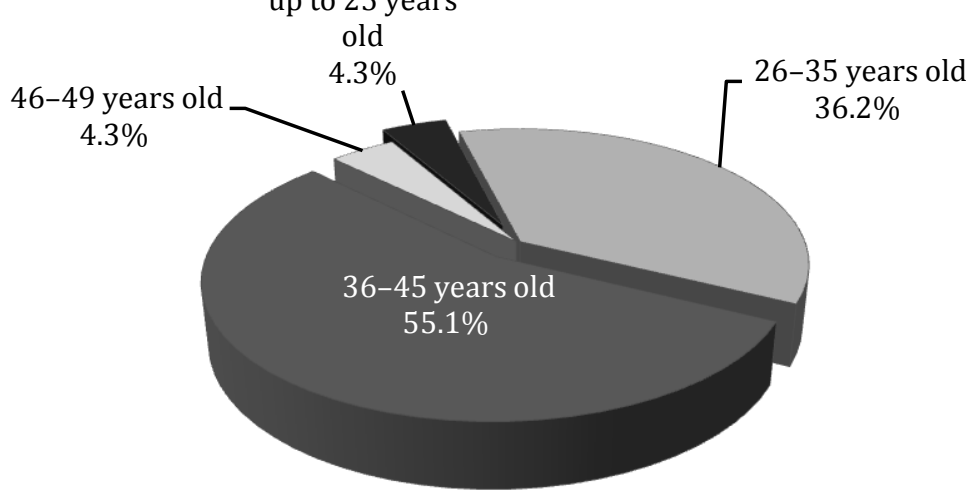

Source: own work based on survey

The orientation for young people is also shown in the answers to the question regarding the employers' preference with regard to the age of potential employees. As much as $79.7 \%$ of answers indicate that employers most frequently employ persons aged 26-35. Younger employees were indicated in $15.9 \%$ of answers, whereas those aged $36-45$ only in $4.3 \%$ of answers. It should be emphasised that none of the aforementioned cases considers persons aged over 50 and the percentage of people aged 36-45 has significantly decreased with regard to the employment of new employees, and people aged 46-50 have not been considered. This is unsettling in the context of the ageing labour force. Unfortunately, human resources planning at organisations do not notice the need to employ older employees, aged over 45 . The obtained results show that the awareness with regard to the ageing of the population is low among employers and employees. This is also confirmed by the fact that only $20.3 \%$ of respondents clearly indicated that they notice the problem of the ageing labour force at their workplace, whereas $23.2 \%$ declared that they rather notice it. Unfortunately, more than half of respondents (56.5\%) claim that the problem is not or is rather not noticed at their workplace. (Fig. 2) In the case of the management, its attitude to older employees is assessed to be at a medium level-3.22 in a 5-point scale.

\section{Figure 2: Noticing the problem of ageing of the labour force at firms}

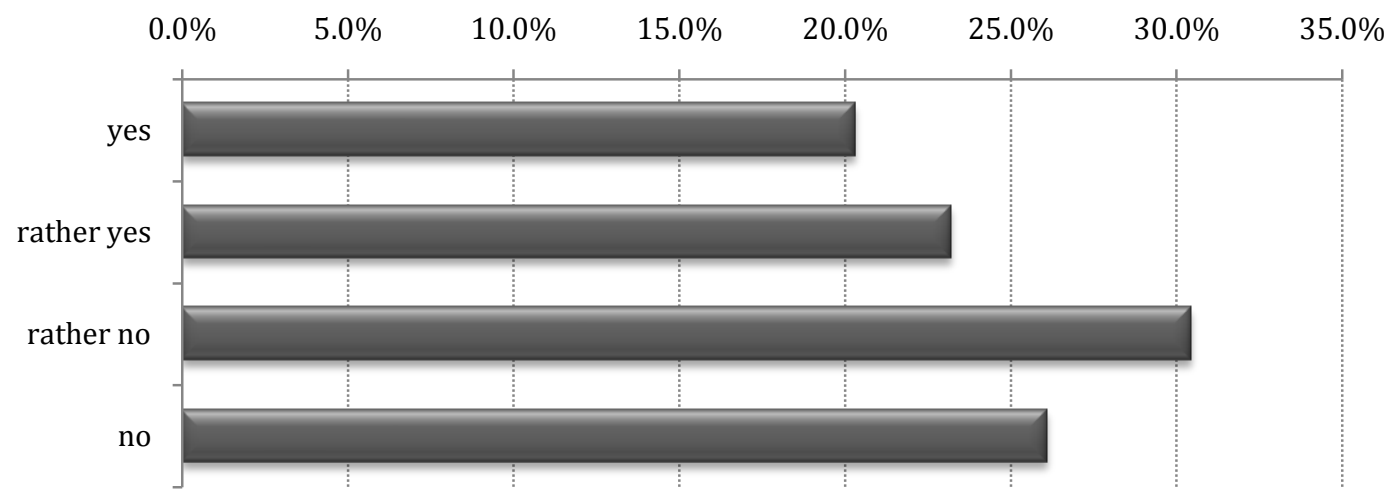

Source: own work based on survey

An important element which favours the efficient introduction of age management to the organisational strategy is the proper atmosphere at the workplace and, primarily, positive attitude to inter-generational cooperation. The existence of such cooperation at the workplace was indicated by $58.0 \%$ of respondents. In $80.0 \%$ of cases it is two-way cooperation, while in the case of $10.0 \%$ it concerns the direction older-younger employees. The evaluation of intensity of that cooperation in both directions is comparable-it is at 3.48 for older-younger cooperation and 3.44 for younger-older cooperation on a 5-point scale. The detailed layout of answers is presented in Fig. 3. 
Figure 3: Evaluation of inter-generational cooperation

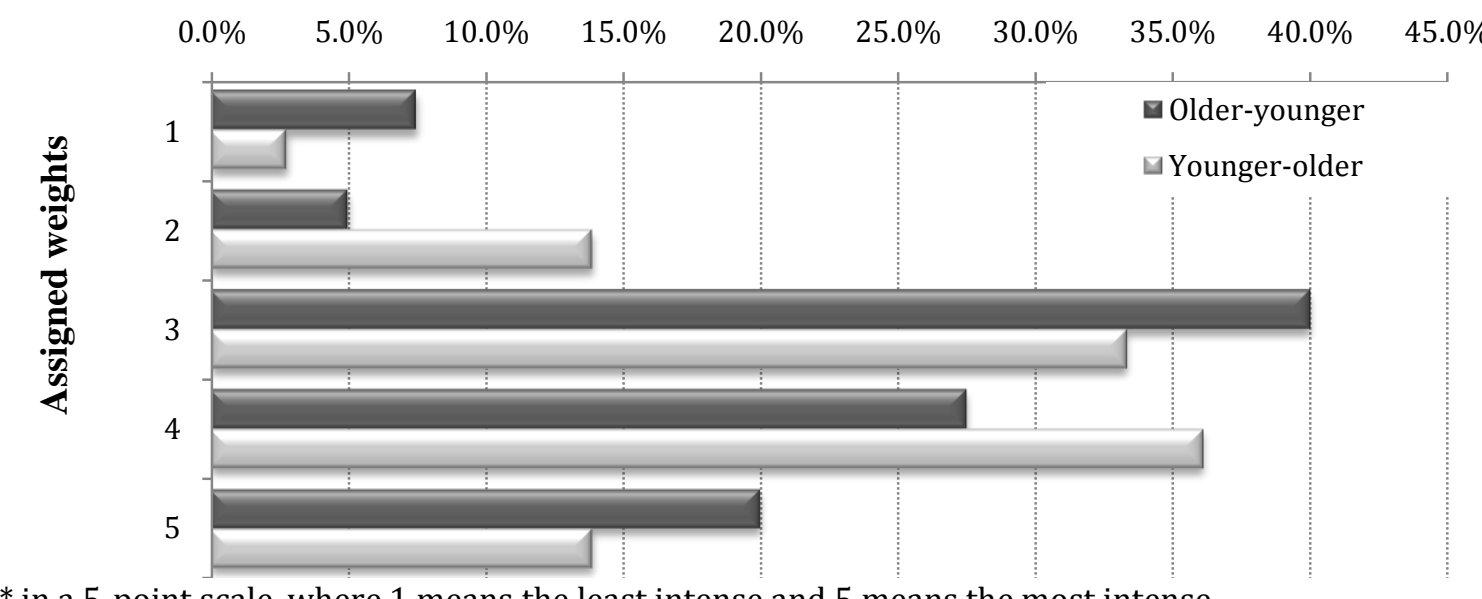

* in a 5-point scale, where 1 means the least intense and 5 means the most intense.

Source: own work based on survey

The results of inter-generational cooperation are mainly focused on the improvement of the relationships, which translates into efficiency and the emergence of new ideas, which favours innovation. The main result of that cooperation is a better atmosphere and the tightening of relationships between employees (29.0\%), which leads to increased efficiency and effectiveness of work $(26.0 \%)$ and impulses for innovative ideas $(22.0 \%)$ Only $8.0 \%$ of respondents indicate that such type of cooperation influences their perception of the firm as an organisation which manages the age of its employees in a positive way (Fig. 3). The introduction of age management requires numerous internal changes at the organisation. One of the barriers for the efficient introduction of activities in that scope is bad habits of employers, who discriminate employees in various respects. Sometimes it becomes visible already during the recruitment. Discrimination does not only result from the position of the employer-it can also be noticed between employees. The analysis of data shows that $1 / 3$ of respondents notice the phenomenon of discrimination among their co-workers. Similar answers were given in that area with regard to employers. As much as $31.9 \%$ of employees indicated that their employer discriminates employees on grounds of sex, age, competence and skills or descent. Considering all answers in that scope, employees most frequently indicated the possessed competence and skills $-29.4 \%$ of all answers. Out of all respondents $1 / 4$ emphasised discrimination on grounds of sex and $23.5 \%$ on grounds of descent. The remaining answers concerned discrimination on grounds of age (22.1\%).

\section{Figure 3: Evaluation of inter-generational cooperation}

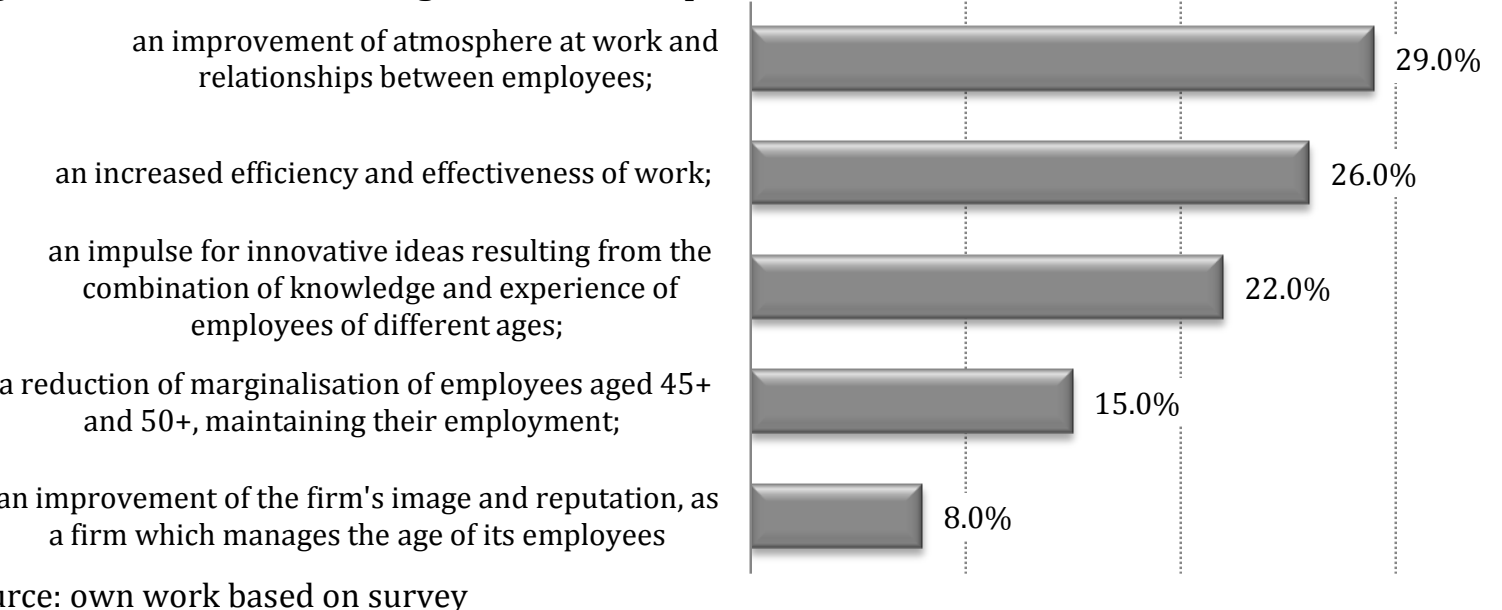

Source: own work based on survey

In order to come to deeper conclusions in that scope a ranking was employed, which indicated that the intensity of those activities falls between 1.82 and 2.9 on a 5-point scale? With regard to individual reasons 
for discriminatory behaviour, the most frequently indicated reason also obtained the highest index of intensity. The situation slightly changed in the case of other reasons for discriminatory behaviour. Discrimination on grounds of sex had the lowest index-below 2.0, whereas discrimination on grounds of age, despite the lowest general number of answers, reached the average weight of 2.13. (Fig. 4)

\section{Figure 4: The intensity of discriminatory behaviour*}

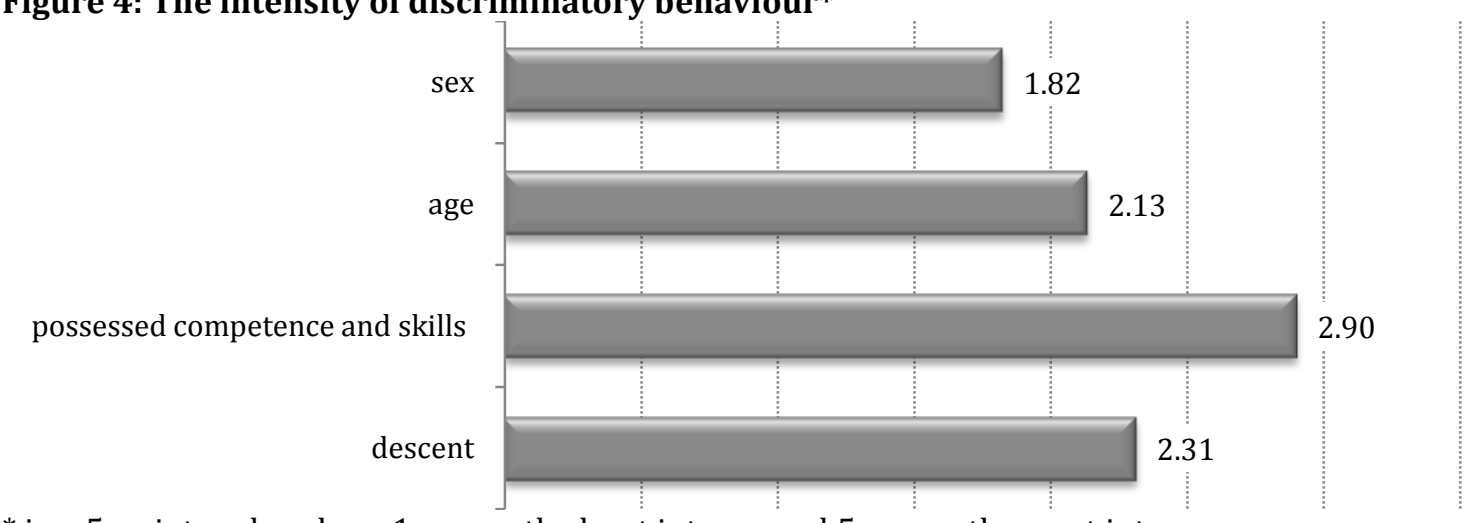

* in a 5-point scale, where 1 means the least intense and 5 means the most intense.

Source: own work based on survey

\section{Conclusion}

The future competitiveness of firms and the efficiency of their operations will depend on the efficient use of older employees and the development of their abilities (Smolarek \& Dziędziora, 2014). In order to efficiently introduce age management at organisations it is required for the management to be highly aware of the existing and increasing threats resulting from the ageing of the labour force and the changing environment in which enterprises function. It is also important to understand, that knowledge, competence and the abilities of senior citizens may increase the internal potential of an organisation, for instance through the creation of inter-generational teams or work groups which share their knowledge and experience. To sum up, it can be seen that at the evaluated organisations:

- the awareness with regard to problems of ageing of the labour force is low;

- there is a clear prevalence of employees aged $26-45$, and employers are most eager to employ people aged 26-35;

- the attitude of the management toward older employees is at a medium level-3.22 in a 5-point scale;

- human resources planning at organisations do not see the need to employ older employees-aged over 45 .

Age management requires a proper atmosphere which favours the acceptance of diversity and cooperation, also with regard to the execution of the equal chances policy. As research at Polish organisations unfortunately shows, the phenomenon of discrimination both on the part of employers and other employees can be noticed, however discrimination on grounds of age is not the dominating type. With regard to intergenerational cooperation it can be pointed out that it exists, but it is executed only in a small scope. Employees notice the results of that cooperation, in particular with regard to the improvement of atmosphere and the tightening of relationships between employees, which is followed by an increased effectiveness and efficiency of work.

\section{References}

Armstrong, M. (2011). Zarządzanie zasobami ludzkimi. Wolters Kluwer Polska, Warszawa.

Casey, B., Metcalf, H. \& Lakey, J. (1993), Human Resource Strategies and the Third Age: Policies and Practices in the UK, in P. Taylor, et al, Age and Employment, London, IPM.

Dzieńdziora, J. \& Smolarek, M. (2009). Zarządzanie zasobami ludzkimi w małych i średnich przedsiębiorstwach. Zeszyty Współczesne zagadnienia zarządzania. Przedsiębiorstwo - biznes - 
region, red. Andrzej Chodyński, Krakowskie Wydawnictwo Edukacyjne sp.z oo - Oficyna Wydawnicza AFM, Kraków, 77-86.

EC. (2006). Ageing and employment: identification of good practice to increase job opportunities and maintain older workers in employment - final report European Commission.

Gorzeń-Mitka, I. (2014). Bricolage in Family Business Management. Przedsiębiorczość i Zarządzanie, T.15, cz.2, z.7, 221-230.

Kandola, R. \& Fullerton, J. (1994). Managing the Mosaic: Diversity in action, Instytut of Personnel and Development, London.

Liwiński, J. \& Sztanderska, U. (2010). Zarządzanie wiekiem w przedsiębiorstwie. Uniwersytet Warszawski, Warszawa.

Lemańska-Majdzik, A. \& Sipa, M. (2015), Selected Aspects of Family Company Management in Employees View in Poland, Aktualne problemy podnikovej sfery 2015. Zbornik vedeckych prac, Vydavatel'stvo EKONÓM. Bratislava, 2, 358-366.

Magd, H. (2003). Management attitudes and perceptions of older workers. International Journal of Contemporary Hospitality Management, 15(7), 393-401.

Mahlberg, B., Freund, I., Cuaresma, J. \& Prskawetz, A. (2013). Ageing, productivity and wages in Austria. Labour Economics, 22, 5-15.

Naegele, G. \& Walker, A. (2006). A guide to good practice in age management. Office for Official Publications of the European Communities.

Okręglicka, M. (2014), Adoption and Use of ICT as a Factor of Development of Small and Medium-sized Enterprises in Poland. Przedsiębiorczość i Zarzqdzanie, 15(7), 393-405.

Pocztowski, A. (2007). Zarządzanie zasobami ludzkimi, Polskie Wydawnictwo Ekonomiczne, Warszawa.

Reday-Mulvay, G. (2005). Working beyond 60: Key policies and practices in Europe. London: Palgrave.

Skibiński, A. (2012). Rozwój ludności województwa śląskiego w okresie transformacji systemowej, in Rączaszek, A. (Eds.). Demograficzne uwarunkowania rozwoju gospodarczego. Studia Ekonomiczne 103, UE Katowice, p.144 - 155.

Smolarek, M. \& Dzieńdziora, J.(2014), Potrzeby rynku pracy w zakresie podnoszenia kwalifikacji pracowników MŚP w obszarze zarządzania. ZS WSH Zarządzanie, 1, 79-90.

Szukalski, P. (2009), Ageizm na polskim rynku pracy, in: Gospodarowanie zasobami pracy na początku XXI wieku. Aspekty makroekonomiczne i regionalne. Horodeński, R., Sadowska-Snarska, C. (Eds.). Warsaw-Białystok IPiSS WSE, 154-167.

EC. (2015). http://ec.europa.eu/eurostat/statistics-explained/index.php/Employment_statistics\#Database (10.05.2015).

Eurofound. (2007). European Age Management Network: The Way Forward? Preliminary Research and Analysis, Equal - European Social Fund, Manuscript Completed in June 2007, 14 http://ec.europa.eu/employment_social/equal_consolidated/data/document/0706-gotagemanet.pdf.

Eurostat, www.ec.europa.eu/eurostat/data/database.

World Data Bank, http://databank.worldbank.org/data/databases.aspx. 